in the interval. $\dagger$ A gravimetric determination throughout. $\ddagger$ An exceedingly florid subject.

Nos. 1,2 , and 6 are the same individual. The results of Column 7 are found from Nos, of Column 6 by multiplying these by $\frac{62}{142}=0.437$.

be 8 in 10,000 parts of blood as the average for healthy blood. This is probably very near the truth. These determinations, as will be seen, have been made partly on measured and partly on weighed quantities of blood. The former are subject to a slight correction for specific gravity. The latter, as already indicated, are to be preferred, but in such cases a delicate balance is a requisite. No. 8 of the series is a gravimetric determination and was made in general confirmation of the grade of the quantities obtained by the present method.

The method now described is applicable to the determination of phosphoric acid in other substances, whether organic or inorganic. The following among other results have been obtained on samples of urine. In each case a preliminary incineration as with blood was made. The result in each case has also been checked by determinations by other methods.

\begin{tabular}{|c|c|c|c|c|c|}
\hline $\begin{array}{l}\text { No. of } \\
\text { speci- } \\
\text { men. }\end{array}$ & $\begin{array}{l}\text { Specific } \\
\text { gravity. }\end{array}$ & Character. & $\begin{array}{l}\text { Quantity } \\
\text { taken. }\end{array}$ & $\begin{array}{c}\text { Per- } \\
\text { centage. }\end{array}$ & Method. \\
\hline \multirow{3}{*}{1} & \multirow{3}{*}{1028\{} & $\begin{array}{c}\text { Of lacta- } \\
\text { tion. }\end{array}$ & $\begin{array}{c}01235 \\
\text { gramme. }\end{array}$ & 0.263 & $\begin{array}{l}\text { Colori } \\
\text { metric. }\end{array}$ \\
\hline & & $"$ & $\left\{\begin{array}{c}10 \text { cubic } \\
\text { centimetres. }\end{array}\right.$ & 0.272 & Volumetrie. \\
\hline & & $"$ & $\left\{\begin{array}{c}10 \text { cubic } \\
\text { centimetres. }\end{array}\right.$ & 0.270 & $\begin{array}{l}\text { Gravi- } \\
\text { metric. }\end{array}$ \\
\hline \multirow{2}{*}{2} & \multirow{2}{*}{1011} & \multirow{2}{*}{$\begin{array}{l}\text { Nephri- } \\
\text { tic. }\end{array}$} & $\begin{array}{c}0.489 \\
\text { gramme. }\end{array}$ & 0.0542 & $\begin{array}{l}\text { Colori- } \\
\text { metric. }\end{array}$ \\
\hline & & & $\begin{array}{c}10 \text { cubic } \\
\text { centimetres. }\end{array}$ & 0.0625 & Volumetric. \\
\hline \multirow[b]{2}{*}{3} & \multirow{2}{*}{10085\{} & \multirow{2}{*}{$\begin{array}{c}\text { Of nervous } \\
\text { excite- } \\
\text { ment. }\end{array}$} & $\begin{array}{c}0.319 \\
\text { gramme. }\end{array}$ & 0.0329 & $\begin{array}{l}\text { Colori- } \\
\text { metric. }\end{array}$ \\
\hline & & & $\begin{array}{l}10 \text { cubic } \\
\text { centimetres. }\end{array}$ & 0.034 & Volumetric \\
\hline
\end{tabular}

A sample of cow's milk gave by this method: first determination, 0.2655 gramme being taken, 0.213 per cent.; a second determination, 0.0705 gramme being taken, 0.219 per cent. A determination of the serum of the blister of a burn gave 26 in 10,000 parts, 0.098 gramme being the quantity taken.

After a year's experience I am of opinion that the method just described yields satisfactory results and in addition to its being applicable as a clinical method for the determination of phosphoric acid in blood it is also likely to prove useful in many other cases where minute quantities of phosphoric acid have to be estimated.

Elgin.

\section{CASE OF RUPTURED GASTRIC ULCER; RECOVERY.}

BY ROBERT THOMSON, M.D. R.U.I., SURGEON TO THE MARGATE COTTAGE HOSPITAL.

A YoUnG woman, aged 19 years, had complained of symptoms of gastric ulcer for some 15 months, 10 of which had been spent under treatment in Cheltenham General Hospital. On July 13th, 1898, at 1 P.M., she partook heartily of a meal consisting of hot roast beef, green peas, spring cabbage, bread, and a tumblerful of ginger-beer, which was followed as usual by pain in the epigastrium and the back. About 5 P.M. she had just sat down to tea when she was hurriedly summoned to attend to some household duties. On rising quickly she was seized with a very severe pain in the epigastrium and with faintness and vomited a small quantity of fluid tinged with blood. The pain continued with increasing intensity and when seen at 8.30 P.M. by Dr. Sawers she was lying on her back with her knees flexed and was rolling about in agony. She was pale, cold, and perspiring profusely. On examination the abdomen was found to be flat, if anything retracted, and the walls were rigid; there was no movement on respiration. There were marked general tenderness, resonance on percussion, and entire absence of hepatic dulness. The diagnosis of a ruptured gastric ulcer was made and she was admitted to the
Margate Cottage Hospital under my care at 10 P.M. On admission the pulse was 110 and the temperature was $96.5^{\circ} \mathrm{F}$.; the other conditions were the same as at 8.30 P.M. Morphine was administered hypodermically, under the influence of which the abdominal muscles relaxed and distension soon appeared. At 11 P.M. she was anæsthetised with ether, a hypodermic injection of ether also being given. A median incision three and a half inches long was made commencing just below the ensiform cartilage, thereby exposing the anterior wall of the stomach which was drawn into the wound and examined, a considerable quantity of grumous fluid at the same time welling up from the space between the stomach and the diaphragm. As this extent of incision failed adequately to expose the rupture in the gastric wall a further incision one and a half inches long was carried upwards and outwards to the left commencing at the upper end of the first incision and terminating at the costal margin, thus affording considerably more room. On careful examination the leakage was found to cccur on. the anterior surface quite close to the lesser curvature, just below the cardia, tbrough an oval aperture about eight millimetres long by four millimetres broad, with thin edges, situated in the base of a small ulcer with thickened indurated margin. No further lesion was discoverable. The rent was included in a double row of silk Lembert sutures, the abdominal cavity was freely washed out with sterilised water, a Keith drainage-tube was inserted through an opening below the umbilicus, and the wound was united by silkworm-gut sutures in one layer. A quarter of a grain of morphine was given hypodermically and the patient passed a good night. On the 14th the morning pulse was 120 and the temperature was $100^{\circ}$. The evening pulse was 136 and the temperature was $102^{\circ}$. There was slight hiccough for two hours which was relieved by sips of hot water. The lower part of the abdomen was considerably distended, abdominal breathing was absent, and there was pain in the epigastrium which was increased by respiration. On the 15th the patient had passed a good night under morphine as before. The morning pulse was 120 and the temperature was $101^{\circ}$. The evening pulse was 116 and the temperature was $102^{\circ}$. The distension was gone, the abdominal breathing was restored, and the epigastric pain was much less and only recurred on respiration. The tongue was furred, dry, and cracked. The patient complained of hunger. During the first 48 hours after operation the bowels acted spontaneously seven times. On the 16 th she had passed a good night. The morning pulse was 106 and the temperature $102^{\circ}$. The even ing pulse was 100 and the temperature was $102^{\circ}$. The drainage-tube having been dry for 24 hours it was removed and replaced by a gauze drain which was also discarded the same evening. The pulse-rate and temperature now gradually fell until the 21st when the normal was reached and maintained. During the night of the 19th some oozing occurred from the upper end of the median incision which continued for about a week. On the 20th six sutures were removed, the remaining ones being left until the 23 rd when they also were removed. Rapid uninterrupted progress continued until July 31st, when the temperature rose to $102^{\circ}$ and pain in the left side was complained of. A soft pleuritic rub was audible in the fifth left intercostal space in the anterior axillary line and dulness subsequently developed below this point. On August 4th the patient was aspirated in the ninth intercostal space below the angle of the scapula and five ounces of turbid serum were drawn off. Within 48 hours the temperature came down to, and remained at, normal and the patient ultimately made a perfect recovery.

Feeding. -The stomach was not lavaged. Frequent sips of hot water were allowed during the first five days, nourishment being maintained by enemata of peptonised beef-tea and milk and meat enules, which did not irritate the rectum as did the beef-tea and milk and which on that account had to be discontinued. Feeding by the mouth was commenced on the sixth day and consisted of small quantities of zyminised milk at frequent intervals and barley water. The amounts which were given and the intervals between were gradually increased and undigested sterilised milk was added by degrees to the zyminised milk. After a few days bland farinaceous foods were largely substituted, then white bread, butter, eggs, boiled white fish, \&c., until in the sixth week the patient was put on ordinary diet again, consisting in addition to the above, of meat, potatoes, vegetable marrow, plain puddings, \&c. During the first fortnight that solid food was given the bowels acted almost involuntarily 
immediately after each meal. There was no sickness at any time after the operation. The only pain worth speaking of ended within the first 48 hours, and digestion of the various :gradations in diet during convalescence was comfortable and easy. Throughout the 12 months which have elapsed since recovery she has been engaged in domestic service, taking ordinary diet, with no dyspepsia except usually on the first day or two of the menstrual periods, a condition which has obtained since their first occurrence.

Remarks. - The early recognition of rupture in these cases and the earliest possible adoption of surgical measures for its relief are of the greatest importance. The exhibition of drugs is useless and only wastes valuable time, while surgical treatment in the majority of recorded cases has been thoroughly satisfactory. As regards the operation itself, the secondary incision was necessitated by the high position of the ulcer affording too limited space for the manipulation of the sutures. The pain and dulness in the left side with rise of temperature on the eighteenth day made me apprehensive of empyema or sub-diaphragmatic abscess, though the temperature had been normal during the preceding 10 days and aspiration was done early solely for diagnostic purposes as the amount of fluid (five ounces) was causing no distress.

I am indebted to Mr. W. Greenwood Sutcliffe for his kind assistance during the operation.

Margate.

\section{PARTURITION COM PLICATED FIBROIDS OF THE UTERUS ; POST- PARTUM HAMORRHAGE; INFU- SION; RECOVERY.}

BY A. J. HELM MONTAGUE, M.D.DURH., L.R.C.P.LOND. M.R.C.S. ENG.,

$$
\text { AND }
$$

\section{B. MOSS-BLUNDELL, L.R.C.P. LOND., M.R.C.S. ENG.}

ON May 9th at 9.30 P.M. Mr. Moss-Blundell was called to see a married woman who had been in labour since 10 A.M. She was a primipara 39 years of age and was not aware, until three months ago when she consulted Dr. Montague, of the character of a tumour in her abdomen. On his arrival Mr. Moss-Blundell found that the pains were strong and of frequent occurrence-every two or three minutes. On vaginal examination the sacral promontory could be felt and the head, which bad not engaged in the pelvis, was lying transversely with the occiput to the veft and did not move with the pains. The os uteri was of about the size of a half-crown, the anterior lip being very cedematous; the membranes had ruptured and there was a fair quantity of blood-stained mucus in the vagina. On abdominal examination a lump attached to the fundus uteri, seemingly of about the size of a Tangerine orange, could be made out. The pulse was 100 and of good volume and regular. As the bowels had not been opened for three days a soap-and-water enema was administered without result. Dr. Montague was summoned, the os uteri meanwhile being dilated by the fingers. On his arrival delivery by the high forceps operation was decided upon. Ohloroform was given and Dr. Montague applied the forceps. $\checkmark$ wing to the pelvic contraction and the small size of the vagina the greatest difficulty was experienced in the extraction of the child. Indeed, at one time the question of perforation of the head was considered, but by dint of much exertion a stillborn child at full term was extracted, not, howerer, without rupture of the perineum which extended to, but did not divide, the external sphincter ani. This was immediately sutured and whilst this operation was in progress the placenta was expelled and one drachm of liquid extract of ergot was given, the uterus contracting well; it was felt to be studded over with round bosses easily palpable. A moment later there was a very severe post-partum hæmorrhage. The uterus was grasped bimanually, 15 minims of ergotin were injected into the buttock, and the vagina was washed out with a hot solution of perchloride of mercury, 1 in 1000 . This checked the bleeding for the moment but the patient was in a very precarious condition. Although the uterus was kneaded continuously, bleeding in small quantities still continued, and about half an hour later the injection of ergotin was repeated. The patient's condition became worse, the pulse was uncountable, the face was pallid, extreme restlessness and sighing respiration were present, the breath felt cool, and she was semi-conscious. 20 minims of ether and one-thirtieth of a grain of strychnine sulphate were injected hypodermically and were repeated after $a$ short interval. Infusion was deemed advisable. At 2 A.M. on the 10th Mr. MossBlundell therefore infused five pints of normal saline solution by the median cephalic vein. From the very commencement of the infusion her condition improved; the pulse was 120 at 3 A.M. and gradually grew stronger through the night. As she vomited and retched continuously, which increased the oozing, ice was given and the retching ceased at 5 A.M., after which there was no more hæmorrhage. At 6 A.M. the patient fell asleep and slept till 8.30 A.Mr. During the day she had balf a drachm of brandy and half a drachm of Valentine's meat juice every hour. In the evening the pulse was 80 and somewhat weak, but the general condition was very satisfactory.

'The patient's progress towards recovery has been uninterrupted and with one exception the temperature has never risen above normal. On the evening of the 13th thrombosis of the cephalic vein was noticed with some slight inflammation along its course and a temperature of $1008^{\circ} \mathrm{F}$., but this subsided on the application of glycerine of belladonna. The bowels were freely opened on the 14th by half an ounce of castor-oil followed by a copious soap-and-water enema. On the 15th the patient was taking mill puddings, fish, \&c., and on the 23rd she was considered convalescent. Vaginal douches of biniodide of mercury, 1 in 1C00, were employed throughout.

Remarks by Dr. MonTAGUE.-There is no doubt in my mind that recovery in this case was entirely due to the infusion of the normal saline solution. The perineum united by first intention. I am greatly indebted to Mr. MossBlundell for the able way in which he seconded my efforts in this case.

Worksop.

\section{A NOTE ON THE ETIOLOGY OF RICKETS.}

\section{BY OHARLES ELGOOD, M.D. LOND.}

AMong the many theories that have been advanced to explain the origin of rickets the most acceptance is undoubtedly given to that which refers the disease to improper feeding. Amply as this cause may account for the disease as it occurs among the poor who frequent the London hospitals, it is when one meets with isolated cases occurring in districts where rickets is less common that one is struck with the mystery that still surrounds the origin of this disease. As it is the duty of every medical practitioner to place on record cases which appear to militate against widely received opinions no apology is offered for the following account.

The daughter of a farm labourer, aged 23 years, living with her parents in a cottage on a small farm, bore in 1885 to a healthy young gamekeeper an illegitimate male child. This boy, who was brought up entirely at the breast, has been several times under my observation, and though I carefully examined him on different occasions in childhood he never presented any single symptom of rickets. In 1886 the woman married a farm labourer, aged 25 years, and for about a year lived with him under her father's roof. The husband, though dull and barmless, was a heavy-looking, boorish fellow of rather slight build, standing five feet nine inches in height. He had coarse features, a sallow skin, and a head of a peculiarly conical shape owing to a remarkable projection in the neighbourhood of the posterior fontanelle. He had a receding forebead and chin and a thick crop of coarse black hair. His chest was narrow and covered with hair. His legs were thin, straight, and also very hairy. There was marked pes planus and his feet turned outwards. In short, there was little noteworthy about him beyond the fact that his cranial peculiarities were the reverse of those found in the subjects of rickets and that his general appearance suggested to the most casual observer a lack of the average amount of intelligence. He 